\title{
Confirmation of Galba truncatula as an intermediate host snail for Calicophoron daubneyi in Great Britain, with evidence of alternative snail species hosting Fasciola hepatica
}

\author{
Rhys Aled Jones, Hefin Wyn Williams, Sarah Dalesman and Peter M. Brophy*
}

\begin{abstract}
Background: Fasciola hepatica is a highly prevalent parasite infecting livestock in Great Britain, while Calicophoron daubneyi is an emerging parasite within the GB livestock industry. Both F. hepatica and C. daubneyi require an intermediate host snail to complete their life-cycles and infect ruminants; however, there has been no confirmation of the intermediate host of $C$. daubneyi in GB, while there are questions regarding alternative host snails to Galba truncatula for F. hepatica. In this study, PCR was used to identify C. daubneyi hosting snail species on Welsh pastures and to identify any alternative snail species hosting $F$. hepatica.

Findings: Two hundred and sixty four snails were collected between May-September 2015 from six farms in mid-Wales known to have livestock infected with C. daubneyi and F. hepatica. Fifteen out of 134 G. truncatula were found positive for $C$. daubneyi, one of which was also positive for $F$. hepatica. Three snail species were found positive for F. hepatica [18/134 G. truncatula, 13/52 Radix balthica, and 3/78 Potamopyrgus antipodarum (New Zealand mud snail)], but no evidence of $C$. daubneyi infection in the latter two species was found.

Conclusion: This study indicates that G. truncatula is a host for C. daubneyi in GB. Galba truncatula is also an established host of $F$. hepatica, and interactions between both species at intermediate host level could potentially occur. Radix balthica and $P$. antipodarum were found positive for $F$. hepatica but not $C$. daubneyi. This could indicate a role for alternative snail species other than G. truncatula in infecting pastures with $F$. hepatica in GB.
\end{abstract}

Keywords: Calicophoron daubneyi, Fasciola hepatica, Galba truncatula, Radix balthica, Potamopyrgus antipodarum, Paramphistomosis, Fasciolosis, Great Britain

\section{Background}

Liver fluke (Fasciola hepatica) and rumen flukes (Paramphistomatidae spp.) are parasitic trematodes prevalent in GB livestock. Liver fluke disease (Fasciolosis) causes an estimated yearly loss of $£ 300$ million for the UK agriculture industry [1], with a study showing that $76 \%$ of the dairy herds in England and Wales are infected [2]. Despite rumen flukes being present in GB for at least half a century [3], it is only in the past decade that these

\footnotetext{
* Correspondence: pmb@aber.ac.uk

Institute of Biological, Environmental and Rural Sciences (IBERS), Aberystwyth University, Aberystwyth SY23 3DA, UK
}

(c) 2015 Jones et al. Open Access This article is distributed under the terms of the Creative Commons Attribution 4.0 International License (http://creativecommons.org/licenses/by/4.0/), which permits unrestricted use, distribution, and reproduction in any medium, provided you give appropriate credit to the original author(s) and the source, provide a link to the Creative Commons license, and indicate if changes were made. The Creative Commons Public Domain Dedication waiver (http://creativecommons.org/publicdomain/zero/1.0/) applies to the data made available in this article, unless otherwise stated.

have been regarded as potentially pathogenic parasites, with increasing reports of disease (paramphistomosis) occurrence [4]. This increase may be due to the establishment of Calicophoron daubneyi as the prominent paramphistome species in GB, replacing Paramphistomum cervi [5]. How C. daubneyi arrived and why it spread across GB has not been confirmed, but increasing animal movements from mainland Europe, where $C$. daubneyi has been present for decades [6], and/or climate change may have facilitated its recent appearance as a parasite of significance. 
Both $F$. hepatica and $C$. daubneyi require a snail as an intermediate host in order to complete their life-cycle, a process in which the parasites exploit their host to develop and multiply rapidly. The main intermediate host of F. hepatica in GB is Galba truncatula (O. F. Müller) [7], however, reports from other countries in Europe have shown that other snail species such as Radix spp. [8, 9], Succinidea spp. [8], Omphiscola glabra (O. F. Müller) [10], and Lymnaea palustris (O. F. Müller) [9] can also act as intermediate hosts for $F$. hepatica. Nevertheless, fundamental questions remain regarding the capabilities of these species to support the development of $F$. hepatica from mother sporocyst to cercariae released into the natural environment. In $G B$, there has been no confirmation of the intermediate snail host of C. daubneyi. Galba truncatula has been shown to be the prominent host of C. daubneyi in Spain [11] and France, where O. glabra, L. palustris, Physa acuta (Draparnaud), and $R$. balthica (L.) have also been shown to host $C$. daubneyi [12]. Other paramphistome species such as $P$. cervi and $C$. calicophoron are known to infect aquatic snails of the family Planorbidae [13] which are present in the freshwater ecosystems of GB.

This lack of clarity regarding the intermediate host of C. daubneyi in GB may have a negative impact on farmers and veterinarians who wish to implement grazing strategies to reduce the burden of $C$. daubneyi in their livestock. There are also questions regarding alternative host species for $F$. hepatica in GB, including whether any shed significant numbers of cercariae onto pasture. In this case study, a panel of snail species found on pastures grazed by ruminants infected with both $F$. hepatica and $C$. daubneyi were screened using PCR assay to detect the presence of infection with these parasites in potential intermediate host snails. The goal was to reveal any $C$. daubneyi transmitting snail species on Welsh pastures and to identify any alternative snail species hosting $F$. hepatica.

\section{Methods}

Between May and September 2015, snails were collected from habitats grazed by animals identified as C. daub$n e y i$ and $F$. hepatica infected via sedimentation faecal egg count (FEC), using the $10 \mathrm{~m}$ transect method [14]. Collected snails were stored in $50 \mathrm{ml}$ tubes and transported to the laboratory where they were identified using morphological characteristics [15]. The snail nomenclature used here follows Anderson [16]. Snails were placed in individual $0.5 \mathrm{ml}$ tubes and crushed using a pellet mixer. Snail DNA was extracted using the Chelex ${ }^{\odot}$ method [17], adapted with the inclusion of $20 \mu \mathrm{l}$ of proteinase K (20 mg/ml, Fisher Scientific, Waltham, USA) prior to incubation at $56{ }^{\circ} \mathrm{C}$. After extraction the sample was centrifuged at $15,000 \mathrm{rpm}$ for $6 \mathrm{~min}$ with the supernatant collected and diluted $\times 10$. Polymerase chain reaction (PCR) amplification was used to screen snails for infection of $F$. hepatica or/and $C$. daubneyi (Additional file 1: Table S1). In brief, snail DNA of the same species were pooled into groups of six, with each pool subjected to PCR on three occasions to detect C. daubneyi infection using primers to amplify a $167 \mathrm{bp}$ strand from the cytochrome $c$ oxidase subunit 1 (cox1) gene (GenBank JQ815200) and $F$. hepatica infection detected using primers to amplify $425 \mathrm{bp}$ strand from the cox 1 gene (GenBank AF216697) [11], and finally as a control amplifying $687 \mathrm{bp}$ and $329 \mathrm{bp}$ amplicons of Lymnaeidae spp. and Potamopyrgus antipodarum (J. E. Gray) 18S rRNA gene, respectively. Snails from positive groups were screened individually in identical manner to detect infection status. A subset of C. daubneyi and F. hepatica cox 1 gene amplicons detected in infected snails, $18 \mathrm{~S}$ gene amplicons for $G$. truncatula and $P$. antipodarum, and ITS2 amplicons for R. balthica (116 bp amplicon amplified using PCR for Radix species ID only), (Additional file 1: Table S1) were sequenced (ABI3100) and aligned to confirm species identity (Geneious Biomatters LTD).

\section{Results}

One hundred and thirty-four G. truncatula were sampled from six farms known to have animals infected with both fluke species (referred to as farms 1-6; Table 1). In total 15 were positive for $C$. daubneyi, and 18 were positive for F. hepatica. One G. truncatula was found positive for $C$. daubneyi and $F$. hepatica. A subset of $C$. daubneyi amplicons $(n=5)$ from positive G. truncatula were sequenced and aligned with the $C$. daubneyi cox 1 sequence (GenBank JQ815200), and showed $100 \%$ similarity (Additional file 2: Figure S1). Fifty-two $R$. balthica and $78 P$. antipodarum were collected from farm 5, with F. hepatica DNA detected in 13 and 3 snails, respectively, but $C$. daubneyi DNA was not found in either species. A subset of $F$. hepatica amplicons from positive $G$. truncatula $(n=2), R$. balthica $(n=1)$ and $P$. antipodarum $(n=1)$ were sequenced and aligned with the $F$. hepatica cox1 sequence (GenBank AF216697) and showed $>99 \%$ similarity (Additional file 2: Figure S2). A subset of F. hepatica-positive G. truncatula $(n=2)$ and $P$. antipodarum $(n=2)$ were sequenced and aligned with their respective 18S gene sequences (GenBank Z73985.1 and JF960455.1, respectively) with all showing $100 \%$ similarity. Radix balthica $(n=2)$ were sequenced and aligned with their ITS2 sequences (GenBank AJ319633.1), and showed $100 \%$ similarity.

\section{Discussion}

With $C$. daubneyi establishing as a prominent parasite within GB's livestock industry, further information is required on its epidemiology to allow veterinarians and 
Table 1 Prevalence of Calicophoron daubneyi and Fasciola hepatica in Galba truncatula collected from six farms in Wales, Great Britain

\begin{tabular}{|c|c|c|c|c|c|}
\hline Farm No. & Month of sampling & $\begin{array}{l}\text { G. truncatula No. of } \\
\text { collected snails }\end{array}$ & $\begin{array}{l}\text { C. daubneyi No. of } \\
\text { infected snails }\end{array}$ & $\begin{array}{l}\text { F. hepatica No. of } \\
\text { infected snails }\end{array}$ & $\begin{array}{l}\text { No. of co-infected } \\
\text { snails }\end{array}$ \\
\hline Farm 1 & May & 35 & 0 & 10 & 0 \\
\hline Farm 2 & June & 1 & 1 & 0 & 0 \\
\hline Farm 3 & June & 24 & 1 & 3 & 0 \\
\hline Farm 4 & July & 28 & 0 & 2 & 0 \\
\hline Farm 5 & August & 26 & 12 & 1 & 1 \\
\hline Farm 6 & September & 20 & 1 & 2 & 0 \\
\hline Total & & 134 & 15 & 18 & 1 \\
\hline
\end{tabular}

livestock producers to implement strategies to minimise its impact. This farm survey found that G. truncatula is a host for C. daubneyi in Wales, which reflects the situation in mainland Europe. If C. daubneyi was introduced to GB during the past decade from animals imported from mainland Europe, the fact that its intermediate host G. truncatula is abundant in GB is likely to have facilitated its establishment. Galba truncatula is already the prominent intermediate host of $F$. hepatica in GB [7]; however, it has been shown in Europe that other lymnaeid snail species can be infected with $F$. hepatica. It is unclear to what extent $F$. hepatica develops in the latter species and whether they may shed significant numbers of cercariae onto pastures. By dissecting a subset of $R$. balthica in our study, free cercariae were seen in snails which were later shown to be positive for $F$. hepatica infection. This would suggest that not only are alternative snail species in GB being infected by $F$. hepatica, but are also shedding cercariae, which could be significant on pastures where G. truncatula are absent [8]. Despite the difficulties recorded in experimental infections of Radix spp. with $F$. hepatica [18], studies have shown that snails infected at the juvenile stage [19] or persistently exposed to $F$. hepatica over successive generations, are more susceptible to infection and eventual shedding [20]. These results could also explain the $F$. hepatica-positive $P$. antipodarum recorded in our study, however, it must be stressed that these infected snails were not dissected, and thus no confirmation of the patency of infection can currently be made.

With $F$. hepatica and $C$. daubneyi now both present in GB there are unanswered questions regarding potential interactions between these parasites within their intermediate snail hosts. There is evidence to suggest that the presence of $C$. daubneyi within a snail population may facilitate infections with $F$. hepatica [21]; this could increase the susceptibility of alternate snail species to $F$. hepatica. However, co-infections with both parasites in G. truncatula, as seen in only one case in this study, have been shown to be rare [22]. This could be down to numerous factors including competition between the two digenean species. Fasciola hepatica has been shown to eliminate C. daubneyi within G. truncatula [23] and it has been suggested that co-infected G. truncatula suffer from increased mortality [24]. These two mechanisms could lead to a wide scale antagonism, where the presence of one digenean within a snail population supresses another. This has been hypothesised to be the reason for the absence of $F$. hepatica in populations of $G$. truncatula infected with Haplometra cylindracea [24, 25], and species of the Echinostomatidae [26]. Co-infections with $C$. daubneyi and $F$. hepatica have been successfully sustained to cercarial shedding within laboratory settings [23], while a high prevalence of digenean infection within a snail population is required for significant antagonism to occur [27]. Therefore, it could be disputed if any significant antagonism occurs between these two species.

\section{Conclusion}

Our study confirms for the first time that $C$. daubneyi is infecting G. truncatula in GB. With a high density of grazing ruminants, widespread populations of G. truncatula, endemic $F$. hepatica levels, newly established $C$. daubneyi, and favourable climate for both parasite and intermediate host, a situation may now arise in GB where significant interaction between $F$. hepatica and $C$. daubneyi occurs at intermediate host level. This could in theory impact positively or negatively on the number of viable cercariae shed on pastures due to a synergistic or antagonistic effect; however, it is unclear if this potential interaction would have any major effect on the prevalence of these parasites in livestock. The role of alternative intermediate host snails for $F$. hepatica and $C$. daubneyi should also not be underestimated, with our data concurring with other studies that F. hepatica is adaptable in infecting and developing in these species. Further research is required on the intermediate hosts of both $C$. daubneyi and F. hepatica and any potential interaction within $\mathrm{GB}$, encompassing greater numbers of snails within a greater extent of snail habitats and farms across a longer period of time. 


\section{Additional files}

Additional file 1: Table S1. Primers and PCR cycling conditions used for detection of snail infection status and confirmation of snail identification to the species level (DOCX $16 \mathrm{~kb}$ )

Additional file 2: Calicophoron daubneyi and Fasciola hepatica sequences amplified from infected snails and aligned with GenBank sequences. Figure S1. Sequences for Calicophoron daubneyi from infected Galba truncatula in farm 1 (GT CD 1), farm 2 (GT CD 4), farm 5 (GT CD 2, GT CD 3), farm 6 (GT CD 5) aligned with C. daubneyi cox1 gene sequence (GenBank JQ815200.1). Figure S2. Sequences for Fasciola hepatica from Galba truncatula co-infected with Calicophoron daubneyi (GT 2 FH), Potamopyrgus antipodarum (PA 1 FH) and Radix balthica (RB $1 \mathrm{FH}$; RB2 FH) aligned with $F$. hepatica cox1 gene sequence (GenBank AF216697.1). (DOCX $17 \mathrm{~kb}$ )

\section{Competing interests}

The authors declare that they have no competing interests.

\section{Authors' contributions}

RAJ, HWW and PMB conceived and designed the study; RAJ and HWW collected the samples; RAJ analysed the samples; all authors contributed to the final manuscript.

\section{Acknowledgements}

The PhD for R.A.J was funded by the Dr Owen Price fund. H.W.W. acknowledges funding from the Coleg Cymraeg Cenedlaethol. S.D is supported by a Leverhulme Trust Early Career Fellowship. P.M.B acknowledges support of Innovate UK. The authors would like to thank all farmers who participated in this study, and Penri James, Dr Neil Mackintosh, and Kathryn Huson for assistance in farm recruitment.

Received: 1 October 2015 Accepted: 16 December 2015

Published online: 23 December 2015

\section{References}

1. Williams DJ. Liver fluke-an overview for practitioners. Cattle Pract. 2014;22: 238-44.

2. McCann CM, Baylis M, Williams DJL. The development of linear regression models using environmental variables to explain the spatial distribution of Fasciola hepatica infection in dairy herds in England and Wales. Int $J$ Parasitol. 2010;40(9):1021-8. doi:10.1016/j.ijpara.2010.02.009.

3. Willmott S. On the species of Paramphistomum Fischoeder, 1901 occurring in Britain and Ireland with notes on some material from the Netherlands and France. J Helminthol. 1950;24(04):155-70.

4. Mason C, Stevenson H, Cox A, Dick I. Disease associated with immature paramphistome infection in sheep. Vet Rec. 2012;170(13):343-4. doi:10.1136/vr.e2368.

5. Gordon DK, Roberts LCP, Lean N, Zadoks RN, Sargison ND, Skuce PJ. Identification of the rumen fluke, Calicophoron daubneyi, in GB livestock: possible implications for liver fluke diagnosis. Vet Parasitol. 2013;195(1-2):65-71. doi:10.1016/j.vetpar.2013.01.014.

6. Szmidt-Adjidé V, Abrous M, Adjidé CC, Dreyfuss G, Lecompte A, Cabaret J, et al. Prevalence of Paramphistomum daubneyi infection in cattle in central France. Vet Parasitol. 2000;87(2-3):133-8. doi:10.1016/S0304-4017(99)00168-5.

7. Ollerenshaw CB. Some observations on the epidemiology of fascioliasis in relation to the timing of molluscicide applications in the control of the disease. Vet Rec. 1971:88(6):152-64

8. Relf V, Good B, McCarthy E, de Waal T. Evidence of Fasciola hepatica infection in Radix peregra and a mollusc of the family Succineidae in Ireland. Vet Parasitol. 2009;63(1-2):152-5. doi:10.1016/j.vetpar.2009.04.003.

9. Novobilsky A, Kasny M, Beran L, Rondelaud D, Hoglund J. Lymnaea palustris and Lymnaea fuscus are potential but uncommon intermediate hosts of Fasciola hepatica in Sweden. (Research)(Report). Parasit Vectors. 2013;6:251.

10. Dreyfuss G, Vignoles P, Rondelaud D. Natural infections of Omphiscola glabra (Lymnaeidae) with Fasciola hepatica in central France. Parasitol Res. 2003:91(6):458-61. doi:10.1007/s00436-003-0892-

11. Martinez-Ibeas AM, Gonzalez-Warleta M, Martinez-Valladares M, CastroHermida JA, Gonzalez-Lanza C, Minambres B, et al. Development and validation of a mtDNA multiplex PCR for identification and discrimination of
Calicophoron daubneyi and Fasciola hepatica in the Galba truncatula snail. Vet Parasitol. 2013:195(1-2):57-64. doi:10.1016/j.vetpar.2012.12.048.

12. Degueurce F, Abrous M, Dreyfuss G, Rondelaud D, Gevrey J. Paramphistomum daubneyi and Fasciola hepatica: the prevalence of natural or experimental infections in four species of freshwater snails in eastern France. J Helminthol. 1999;73(03):197-202.

13. Sey O. Revision of the amphistomes of European ruminants. Parasit Hung. 1980;13:13-25.

14. Malone JB, Loyacano AF, Hugh-Jones ME, Corkum KC. A three-year study on seasonal transmission and control of Fasciola hepatica of cattle in Louisiana. Prev Vet Med. 1984:3(:131-41. doi:10.1016/0167-5877(84)90003-5.

15. Macan T. A key to the British fresh- and brackish-water gastropods : with notes on their ecology. 4th ed. Freshwater Biological Association: Ambleside; 1977.

16. Anderson R. An annotated list of the non-marine mollusca of Britain and Ireland. J Conchol. 2005:38:607-38.

17. Caron Y, Righi S, Lempereur L, Saegerman C, Losson B. An optimized DNA extraction and multiplex PCR for the detection of Fasciola sp. in lymnaeid snails. Vet Parasitol. 2011;178(1-2):93-9. doi:10.1016/j.vetpar.2010.12.020.

18. Smith G, Crombie JA. The rate of attachment of Fasciola hepatica miracidia to various species of lymnaeid. J Parasitol. 1982;68(5):965-6.

19. Dreyfuss $G$, Vignoles P. Rondelaud D. Variability of Fasciola hepatica infection in Lymnaea ovata in relation to snail population and snail age. Parasitol Res. 2000:86(1):69-73.

20. Rondelaud D, Titi A, Vignoles P, Mekroud A, Dreyfuss G. Adaptation of Lymnaea fuscus and Radix balthica to Fasciola hepatica through the experimental infection of several successive snail generations. Parasit Vectors. 2014;7:296. doi:10.1186/1756-3305-7-296.

21. Abrous M, Rondelaud D, Dreyfuss G, Cabaret J. Unusual transmission of the liver fluke, Fasciola hepatica, by Lymnaea glabra or Planorbis leucostoma in France. J Parasitol. 1998:84(6):1257-9.

22. Rondelaud D, Vignoles P, Dreyfuss G. Fasciola hepatica: the developmental patterns of redial generations in naturally infected Galba truncatula. Parasitol Res. 2004;94(3):183-7. doi:10.1007/s00436-004-1191-8.

23. Rondelaud D, Vignoles P, Dreyfuss G. Parasite development and visceral pathology in Galba truncatula co-infected with Fasciola hepatica and Paramphistomum daubneyi. J Helminthol. 2007:81(03):317-22.

24. Goumghar MD, Abrous M, Ferdonnet D, Dreyfuss G, Rondelaud D. Prevalence of Haplometra cylindracea infection in three species of Lymnaea snails in central France. Parasitol Res. 2000;86(4):337-9.

25. Whitelaw A, Fawcett AR. Biological control of liver fluke. Vet Rec. 1982; 110(21):500-1. doi:10.1136/vr.110.21.500.

26. Gordon HM, Boray JC. Controlling liver-fluke: a case for wildlife conservation? Vet Rec. 1970;86(10):288-9. doi:10.1136/vr.86.10.288.

27. Kuris A. Guild structure of larval trematodes in molluscan hosts: prevalence, dominance and significance of competition. In: Esch G, Bush A, Aho J, editors. Parasite Communities. Patterns and Processes. Netherlands: Springer; 1990. p. 69-100.

\section{Submit your next manuscript to BioMed Central} and we will help you at every step:

- We accept pre-submission inquiries

- Our selector tool helps you to find the most relevant journal

- We provide round the clock customer support

- Convenient online submission

- Thorough peer review

- Inclusion in PubMed and all major indexing services

- Maximum visibility for your research

Submit your manuscript at www.biomedcentral.com/submit 